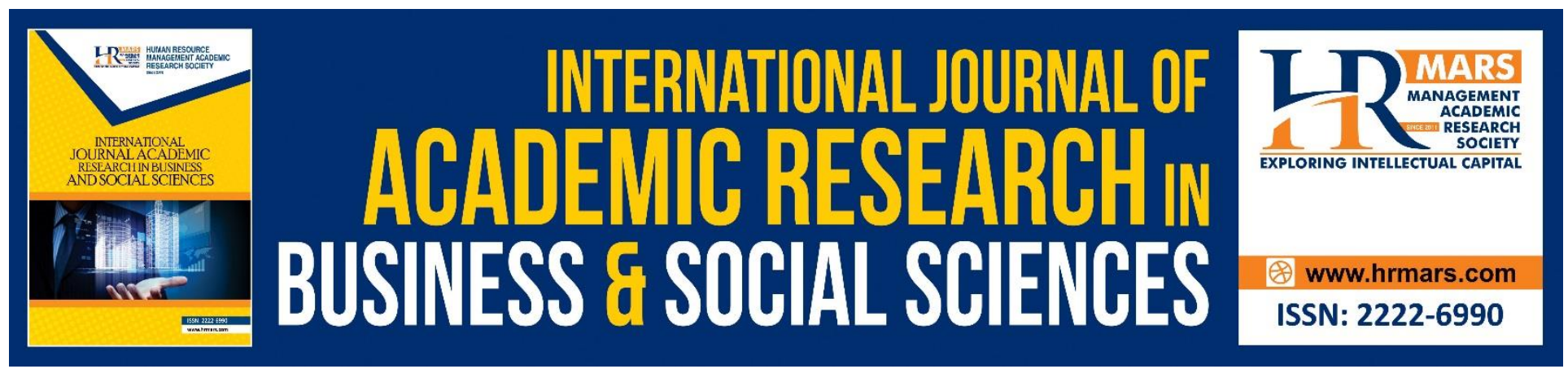

\title{
Influence of School Culture and Climate in Tamil Schools, Malaysia
}

\author{
Thiruchelvan Koundyannan, Suhaida Abd Kadir, Ramli Basri, Ahmad Fauzi \\ Mohd Ayub
}

To Link this Article: http://dx.doi.org/10.6007/IJARBSS/v10-i5/7167

DOI:10.6007/IJARBSS/v10-i5/7167

Received: 06 March 2020, Revised: 09 April 2020, Accepted: 24 April 2020

Published Online: 02 May 2020

In-Text Citation: (Thiruchelvan et al., 2020)

To Cite this Article: Thiruchelvan, K., Kadir, S. A., Basri, R., \& Ayub, A. F. M. (2020).. Influence of School Culture and Climate in Tamil Schools, Malaysia. International Journal of Academic Research in Business and Social Sciences, 10(5), 1-12.

Copyright: (c) 2020 The Author(s)

Published by Human Resource Management Academic Research Society (www.hrmars.com)

This article is published under the Creative Commons Attribution (CC BY 4.0) license. Anyone may reproduce, distribute, translate and create derivative works of this article (for both commercial and non-commercial purposes), subject to full attribution to the original publication and authors. The full terms of this license may be seen

at: http://creativecommons.org/licences/by/4.0/legalcode

Vol. 10, No. 5, 2020, Pg. 1 - 12

http://hrmars.com/index.php/pages/detail/IJARBSS

JOURNAL HOMEPAGE

Full Terms \& Conditions of access and use can be found at http://hrmars.com/index.php/pages/detail/publication-ethics 


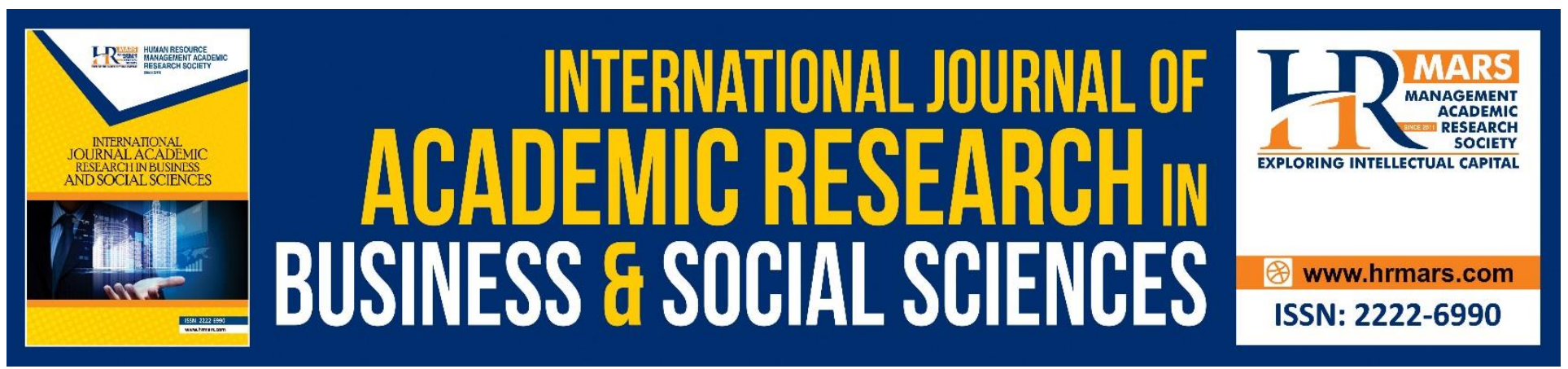

\title{
Influence of School Culture and Climate in Tamil Schools, Malaysia
}

\author{
Koundyannan Thiruchelvan, Suhaida Abd Kadir, Ramli Basri, \\ Ahmad Fauzi Mohd Ayub \\ Faculty of Educational Studies, Universiti Putra Malaysia, 43400 Serdang Selangor, Malaysia \\ Email: suhaida@upm.edu.my
}

\begin{abstract}
School culture and climate are two uncertain aspects of the management and administration of schools in a VUCA world. This study was conducted to examine the influence of factors in the school culture and climate for the school effectiveness of Sekolah Jenis Kebangsaan Tamil (SJKT) in Malaysia. This research involved a total of 312 teachers from 82 SJKT schools in Peninsular Malaysia. Data were collected by strata using the School Culture Survey, School Climate Instrument and School Effectiveness Instrument. The results of the stepwise multiple regression analysis show that the School Culture Regression Model P5 (unity of purpose, collaborative leadership, learning partnership, professional development, and teacher's collaboration) contributed for $65.0 \%\left(\mathrm{R}^{2}=.644\right)$ changes in variance in school effectiveness $[F(5,306)=113.609, p<0.5]$. The school climate regression model P4 (leadership, environment, instruction, and collaborations) contributed $67.8 \%\left(\mathrm{R}^{2}=.673\right)$ of the variance in school effectiveness $[F(4,307)=161.265, p<0.5]$. The combination of school culture $(\beta=.542, p<0.5)$ and school climate $(\beta=.317, p<0.5)$ significantly contributed $66.8 \%\left(R^{2}=.666\right)$ of the variance change $[F(2,309)=310.731, p<0.5]$. The results of the stepwise multiple regression analysis showed that school Culture influence $(\beta=.542, p<.05)$ higher than school climate $(\beta=.317, p<.05)$. This model contributes to predicting the impact of school culture and climate on school effectiveness.

Keywords: School Culture, School Climate, School Effectiveness.
\end{abstract}

\section{Introduction}

The education world faces challenges in creating a balance of human capital and ability to compete internationally in a volatile, uncertain, complex and ambiguous (VUCA) world. In order to address these challenging demands, the management and administration of the schools takes various steps in improving the system (Gonder \& Hymes, 1994). The education system in Malaysia has undergone drastic changes over a short period of time. The drastic changes in education system in Malaysia has resulted in uncertainty of the education system. School effectiveness is important even if multiple changes are implemented over a period of time. 
School climate and culture are among the most important factors in determining the success of a school and maintain school effectiveness (Patterson, Dulmus, Maguin, \& Critalli, 2014). Both of these concepts are important in improving school effectiveness. However, there is often confusion between school culture and climate among school management administrators. Both factors influence beliefs and attitudes of every aspect of school function. The school culture and the climate shared by the stakeholders to ensure the sustainability of objective achievement (Bates, 1987). Hence, leadership direct and indirect needs to shape the school cultural and climate situation for school improvement. In this process, school leadership becomes a mediator in shaping school culture and climate (Hamidah \& Cing, 2014; Bellibas \& Liu, 2018).

Meanwhile, Mortimore (2001) lists school characteristics such as having strong principalship in management's focus on improving the quality of teaching, building a school climate in which every student is within a set level of achievement, have a well-disciplined atmosphere without the need to build self-discipline, calm and unobtrusive, but comfortable in a teaching environment, to prioritize the teaching process in which schools work hard to ensure the goals of teaching are implemented systematically and effectively and systematically assesses student progress, where principals and teachers monitor student progress based on teaching needs and objectives.

In the management of school culture and climate both factors seen as one entity and some aspects of it are ignored or abandoned. School management needs to understand and identify the specific dimensions of school culture and school climate separately in order to be managed effectively. This separate management can contribute to improving the effectiveness of the school. Hoy, Tarter and Kottkamp (1991) argues that these two factors have differences in school culture from the anthropological point of view and the school climate from the psychological point of view. So this study will explore the difference between school effectiveness. Therefore, school culture and school climate need to be studied separately and in close contact with existing methodologies in order to enhance school effectiveness.

\section{Objectives}

There were three main objectives focus in this research. The purpose of this study was to determine:

i. School culture dimensions as predicable factor of school effectiveness.

ii. School climate dimensions as predicable factor of school effectiveness.

iii. Contribution of school culture and climate variable as predicable factor of school effectiveness.

\section{Methodology}

This is a survey study, involving a total of 312 teachers from SJKT in peninsular Malaysia. Data for this study were collected using the School Culture Survey Instrument (Gruenert, 1998), School Climate Instrument (Ross \& Lowther, 2003) and School Effectiveness Instrument (Lezotte \& Snyder, 2011). The instrument for school culture has six dimensions of collaborative leadership, teacher collaboration, professional development, collegial support, unity of purpose and learning partnership. The school climate instrument has seven dimensions based on collaboration, environment, expectations, instruction, involvement, leadership and order. The data obtained from the questionnaire were analyzed using SPSS version 24 . The regression and stepwise regression analysis widely used method to describe the predicable factors. 
INTERNATIONAL JOURNAL OF ACADEMIC RESEARCH IN BUSINESS AND SOCIAL SCIENCES Vol. 10, No. 5, May, 2020, E-ISSN: 2222-6990 @ 2020 HRMARS

\section{Theoretical Framework}

This study was designed based on the theory of organization culture (Schein, 2004) and school climate (Anderson, 1982). It defines both school culture and climate as independent variables and school effectiveness as dependent variable. Theory of the Organization Culture and Theory of School Climate and Open System Theory used as framework of study.

\section{School Culture and School Climate}

A peaceful and comfortable school environment suitable for teaching and learning is considered to have an effective school climate. Halpin and Croft (1963) a pioneer in school climate studies, said that the school climate reflects the personality of the individual and how the teacher strives to achieve the school's climate warming. Furthermore, school climate as the social and cultural condition of the school that influenced the behavior of the people within it (Howard, 1974).

Organizational culture is the basic concept in management theory. In the present study the management area assumes that organizational culture includes assumptions, attitudes, beliefs, rituals, traditions, knowledge, languages, norms and values shared by all members in an organization (Schein, 1990). While the school climate makes the people feel or sense their school. The school environment interacts complexly in influencing students, staff and family members in appreciating the school. Based on Anderson (1982) there are three main dimensions of the school climate that's physical, social, and elemental aspects of trust, value and sharing of information.

School climate refers to the impact of the school environment on students including teaching practices, cultural diversity and relationships between administrators, teachers, parents, and students (Zullig, Koopman, Patton, \& Ubbes, 2010). School climate is also the perception, feelings and expectations held by members of the school and community as parents. Creating a positive school climate requires recognition of students as a key focus as well as leadership, efficient staff and shared goals with students and the community. In addition, a positive school climate should foster mutual respect and cooperation between the school staff and the community (Rudasill, Snyder, Levinson, \& Adelson, 2017).

Whereas in the culture, it refers to teachers and school staff working with the beliefs, values and assumptions they share. School culture also includes set of values, beliefs, assumptions, and ways in which the school identifies standards for shaping student behavior. Researchers emphasize that school climate and culture are two different concepts. According to Houtte (2005) school culture is understood as a constricted concept and involves only individuals and their beliefs, assumptions and thoughts. While the school climate reflects the broader concept, it involves more complex elements than the aspects of the quality of the environment.

Gruenert (1998) identifies six dimensions to describe the collaborative school culture which is describing collaborative leadership as school leaders who establish and maintain collaborative relationships with school staff; teacher collaboration concerns working together and sharing pedagogical information; unity of purpose refers to the school mission and its influence on teaching; professional development encompasses all types of teachers learning to maintain current knowledge about educational practices; collegial support which includes teachers' willingness to help each other 
INTERNATIONAL JOURNAL OF ACADEMIC RESEARCH IN BUSINESS AND SOCIAL SCIENCES Vol. 10, No. 5, May, 2020, E-ISSN: 2222-6990 @ 2020 HRMARS

when there is a problem; and learning partnership refers to cooperation between teachers and parents based on common expectations towards student achievements.

Involvement was found as the strongest finding and defined as the amount of parent and community collaboration which occurs within the school. Within the school climate aspect, the community and parent involvement was positively correlated with student academic achievement (Ross \& Lowther, 2003). The inventory helps school leaders gauge school personnel perceptions and address climaterelated factors that hinder a school's effectiveness. The $\mathrm{SCl}$ includes seven dimensions that are both theoretically and empirically linked with effective school organization climates. The seven dimensions are based on collaboration, environment, expectations, instruction, involvement, leadership and order. For example, "environment" refers to a positive learning environment and "involvement" to parent and community engagement with the school. The survey is intended for school staff and consists of 49 items. All the dimension has seven items accordingly.

\section{Research Finding \\ Demography}

In sum, 312 teachers from SJKT in peninsular Malaysia were involved in the survey. Table 1, shows in terms of gender, there were $25.0 \%$ male teachers and $75.0 \%$ female teachers. In terms of experience, a total of $10.9 \%$ experienced teachers taught between 1 to 5 years, $22.8 \%$ had 6 and 10 years of experience, $26.9 \%$ had 11 to 15 years of experience, $17.6 \%$ had 16 to 20 years of experience and $21.8 \%$ had 20 years of experience or more. In terms of academic qualifications, $15.1 \%$ of teachers qualified with certificates/ diplomas, $67.6 \%$ of teachers qualified with a bachelor's degree, $17.0 \%$ of teachers qualified with a bachelor's degree and $3.0 \%$ teachers with doctorate.

Table 1: Respondent Profile

\begin{tabular}{llcc}
\hline Item & Category & Respondent & $\begin{array}{c}\text { Percentage } \\
\text { (\%) }\end{array}$ \\
\hline School & SJKT & 312 & 100 \\
\hline Gender & Male & 78 & 25 \\
& Female & 234 & 75 \\
\hline Teaching & $\leq 5$ & 34 & 10.9 \\
experience & $6-10$ Years & 71 & 22.8 \\
& $11-15$ Years & 84 & 26.9 \\
& $16-20$ Years & 55 & 17.6 \\
& $\geq 20$ Years & 68 & 21.8 \\
\hline Academic & Certificate/Diploma & 47 & 15.1 \\
qualification & Degree & 211 & 67.6 \\
& Masters & 53 & 17.0 \\
& Doctorate & 1 & 3 \\
\hline
\end{tabular}


INTERNATIONAL JOURNAL OF ACADEMIC RESEARCH IN BUSINESS AND SOCIAL SCIENCES

Vol. 10, No. 5, May, 2020, E-ISSN: 2222-6990 @ 2020 HRMARS

\section{School Culture as Predictable Factor for School Effectiveness}

Table 2, shows that unity of purpose, collaborative leadership, professional development, learning partnership and teacher's collaboration have significant beta $(\beta)$ values. This means that each of these variables explained the variance in school effectiveness significantly after the influence of the other variables was statistically controlled through multiple regression analysis. Professional collegial support was not included in the regression model because these variable had $\beta$ values that were too small and insignificant after the influence of other variables were controlled (Chua, 2009).

Table 2: The Beta Values of the School Culture Variables

\begin{tabular}{lll}
\hline Dimension & Beta & Sig. \\
\hline Unity of purpose & $\beta=.315^{*}$ & .000 \\
Collaborative leadership & $\beta=.276^{*}$ & .000 \\
Professional development & $\beta=.146^{*}$ & .002 \\
Learning partnership & $\beta=.134^{*}$ & .002 \\
Teacher's collaboration & $\beta=.095^{*}$ & .049 \\
Collegial support & $\beta=.074$ & .091 \\
\hline
\end{tabular}

Note: Significant at level ${ }^{*} p<0.05$

The results of the multiple regression analysis in table 3 and 4, show that the change in the four school culture variables included in the regeneration model follows a significant $\beta$ value. Unity of purpose $(\beta=.663, p<0.5)$ significantly contributed as much as $43.9 \%\left(R^{2}=.437\right)$ changes in variance $[F(1,310)=242.795, p<0.5]$. The combination of unity of purpose $(\beta=.467, p<0.5)$ and collaborative leadership $(\beta=.443, p<0.5)$ contributed $59.7 \%\left(R^{2}=595\right)$ changes in variance $[F(2,309)=229.196$, $p<0.5]$.

Table 3: Linear Regression Predictor of School Culture

\begin{tabular}{lcccrcc}
\multicolumn{1}{c}{ Model } & $\boldsymbol{R}$ & $\boldsymbol{R}^{\mathbf{2}}$ & ${ }^{\wedge} \boldsymbol{R}^{\mathbf{2}}$ & \multicolumn{1}{c}{$\mathbf{d f}$} & $\boldsymbol{F}$ & Sig. \\
\hline Unity of Purpose & .663 & .439 & .437 & 1 & 242.795 & .000 \\
& & & & 310 & & \\
& & & & 311 & & \\
\hline Collaborative & .773 & .597 & .595 & 2 & 229.196 & .000 \\
Leadership & & & & 309 & & \\
& & & & 311 & & \\
\hline Learning & .793 & .628 & .624 & 3 & 173.395 & .000 \\
Partnership & & & & 308 & & \\
& & & & 311 & & \\
\hline Professional & .803 & .645 & .640 & 4 & 139.348 & .000 \\
Development & & & & 307 & & \\
& & & & 311 & & \\
\hline Teacher's & .806 & .650 & .644 & 5 & 113.609 & .000 \\
Collaboration & & & & 306 & & \\
& & & & 311 & & \\
\hline
\end{tabular}

Note: Significant level at $p<0.05$ 
INTERNATIONAL JOURNAL OF ACADEMIC RESEARCH IN BUSINESS AND SOCIAL SCIENCES

Vol. 10, No. 5, May, 2020, E-ISSN: 2222-6990 @ 2020 HRMARS

Then the combination of unity of purpose $(\beta=.405, p<0.5)$, collaborative leadership $(\beta=.369, p<0.5)$ and learning partnership $(\beta=.210, p<0.5)$ contributed $62.8 \%\left(R^{2}=.624\right)$ change in variance $[F(3,308)=173.395, p<0.5]$. Combination of unity of purpose $(\beta=.347, p<0.5)$, collaborative leadership $(\beta=.321, p<0.5)$, professional development $(\beta=.174, p<0.5)$ and learning partnership $(\beta=.172, p<0.5)$ contributed $64.5 \%\left(R^{2}=.640\right)$ change in variance $[F(3,307)=139.348, p<0.5]$. Then the combination of unity of purpose $(\beta=.336, p<0.5)$, collaborative leadership $(\beta=.286, p<0.5)$, learning partnership $(\beta=.153, p<0.5)$, professional development $(\beta=.149, p<0.5)$ and teacher's collaboration $(\beta=.101$, $p<0.5)$ contributed $65.0 \%\left(R^{2}=.644\right)$ change in variance $[\mathrm{F}(3,306)=113.609, \mathrm{p}<0.5]$. The regression equation is given as follows: $Y=1.463+0.237_{1}+0.173_{2}+0.090_{3}+0.107_{4}+0.062_{5}$.

Table 4: Coefficient Values School Culture Factor as Predictors

\begin{tabular}{clrrrr}
\hline Model & \multicolumn{1}{c}{ Variable } & B & Std. Error & Beta & \multicolumn{1}{c}{ t } \\
\hline P1 & Constant & 2.210 & .136 & & 16.227 \\
& Unity of Purpose & .468 & .030 & .663 & 15.582 \\
\hline P2 & Constant & 1.723 & .124 & & 13.924 \\
& Unity of Purpose & .330 & .028 & .467 & 11.617 \\
& Collaborative Leadership & .268 & .024 & .443 & 11.016 \\
\hline P3 & Constant & 1.604 & .121 &. & 13.212 \\
& Unity of Purpose & .284 & .029 & .405 & 9.980 \\
& Collaborative Leadership & .224 & .025 & .369 & 8.923 \\
& Learning Partnership & .124 & .025 & .210 & 5.048 \\
\hline P4 & Constant & 1.469 & .124 & & 11.849 \\
& Unity of Purpose & .245 & .030 & .347 & 8.154 \\
& Collaborative Leadership & .194 & .026 & .321 & 7.544 \\
& Learning Partnership & .102 & .025 & .172 & 4.112 \\
& Professional Development & .124 & .033 & .174 & 3.803 \\
\hline P5 & Constant & 1.463 & .123 & & 11.861 \\
& Unity of Purpose & .237 & .030 & .336 & 7.860 \\
& Collaborative Leadership & .173 & .027 & .286 & 6.304 \\
& Professional Development & .090 & .025 & .153 & 3.594 \\
& Learning Partnership & .107 & .034 & .149 & 3.191 \\
& Teacher's Collaboration & .062 & .029 & .101 & 2.104 \\
\hline
\end{tabular}

Dependent Variable: School Effectiveness, $P=$ Predicable Variable

The results of the stepwise multiple regression analysis show that the P5 regression model (unity of purpose, collaborative leadership, learning partnership, professional development, and teacher's collaboration) contributed for $65.0 \%\left(R^{2}=.644\right)$ changes in variance in school effectiveness $[F(5,306)$ $=113.609, p<0.5]$.

The influence of unity of purpose $(\beta=.336, p<0.5)$ was highest follow by, collaborative leadership $(\beta=.284, p<0.5)$, learning partnership $(\beta=.153, p<0.5)$, professional development $(\beta=.149, p<0.5)$, and teacher's collaboration $(\beta=.101, p<0.5)$. School culture factors contributes in predicting the school effectiveness in SJKT. 
INTERNATIONAL JOURNAL OF ACADEMIC RESEARCH IN BUSINESS AND SOCIAL SCIENCES

Vol. 10, No. 5, May, 2020, E-ISSN: 2222-6990 ㄷ 2020 HRMARS

\section{School Climate as Predictable Factor for School Effectiveness}

Table 5, shows that leadership, instruction, expectations and environment have significant beta $(\beta)$ values. This means that each of these variables explained the variance in school effectiveness significantly after the influence of the other variables was statistically controlled through multiple regression analysis. Collaboration, involvement and order were not included in the regression model because these variables had $\beta$ values that were too small and insignificant after the influence of other variables.

Table 5: The Beta Values of the School Climate Variables

\begin{tabular}{lll}
\hline Dimension & Beta & Sig. \\
\hline Leadership & $\beta=.385^{*}$ & .000 \\
Instruction & $\beta=.216^{*}$ & .000 \\
Collaboration & $\beta=.188^{*}$ & .000 \\
Environment & $\beta=.187^{*}$ & .000 \\
Expectations & $\beta=.049$ & .249 \\
Order & $\beta=-.022$ & .632 \\
Involvement & $\beta=.001$ & .971 \\
\hline
\end{tabular}

Note: Significant level at $p<0.05$

The results of the multiple regression analysis in table 6 and 7 showed that four school climate variables were included in the regression model according to significant $\beta$ values. Leadership ( $\beta=.737$, $\mathrm{p}<0.5)$ contribute for a significant $54.4 \%\left(R^{2}=.542\right)$ variance change $[\mathrm{F}(1,310)=369.091, \mathrm{p}<0.5]$. The combination of leadership $(\beta=.535, p<0.5)$ and environment $(\beta=.339, p<0.5)$ contribute for $61.8 \%$ $\left(R^{2}=.615\right)$ variance change $[\mathrm{F}(2,309)=249.669, \mathrm{p}<0.5]$. Subsequent combinations of leadership $(\beta=.444, p<0.5)$, environment $(\beta=.280, p<0.5)$ instruction $(\beta=.251, p<0.5)$ and accounted for $66.3 \%$ $\left(R^{2}=.659\right)$ variance change $[\mathrm{F}(3,308)=201.661, \mathrm{p}<0.5]$. Finally, the combination of leadership $(\beta=.379, p<0.5)$, environment $(\beta=.192, p<0.5)$, instruction $(\beta=.231, p<0.5)$, collaborations $(\beta=.192$, $\mathrm{p}<0.5)$ and accounted for $67.8 \%\left(R^{2}=.673\right)$ variance change $[\mathrm{F}(4,307)=161.265, \mathrm{p}<0.5]$. The regression equation is given as follows: $Y=1.151+0.305_{1}+0.137_{2}+0.175_{3}+0.132_{4}$

Table 6: Linear Regression Predictor of School Climate

\begin{tabular}{|c|c|c|c|c|c|c|}
\hline Model & $\boldsymbol{R}$ & $R^{2}$ & ${ }^{\wedge} R^{2}$ & df & $\mathbf{F}$ & Sig. \\
\hline \multirow[t]{3}{*}{ Leadership } & .737 & .544 & .542 & 1 & 369.091 & .000 \\
\hline & & & & 310 & & \\
\hline & & & & 311 & & \\
\hline \multirow[t]{3}{*}{ Environment } & .786 & .618 & .615 & 2 & 249.669 & .000 \\
\hline & & & & 309 & & \\
\hline & & & & 311 & & \\
\hline \multirow[t]{3}{*}{ Collaboration } & 814 & .663 & .659 & 3 & 201.661 & .000 \\
\hline & & & & 308 & & \\
\hline & & & & 311 & & \\
\hline \multirow[t]{3}{*}{ Instruction } & .823 & .678 & .673 & 4 & 161.265 & .000 \\
\hline & & & & 307 & & \\
\hline & & & & 311 & & \\
\hline
\end{tabular}

Note: Significant level $p<0.05$ 
INTERNATIONAL JOURNAL OF ACADEMIC RESEARCH IN BUSINESS AND SOCIAL SCIENCES Vol. 10, No. 5, May, 2020, E-ISSN: 2222-6990 @ 2020 HRMARS

The results of the Stepwise Multiple Regression analysis showed that the P4 regression model (leadership, environment, instruction, and collaborations) contributed $67.8 \%\left(R^{2}=.673\right)$ of the variance in school effectiveness $[F(4,307)=161.265, p<0.5]$. Leadership influence $(\beta=.379, p<.05)$ was highest, followed by instruction $(\beta=.192, p<.05)$, environment $(\beta=.231, p<.05)$ and expectations $(\beta=.192, p<.05)$. School climate factors contributes to predicting school effectiveness in SJKT.

Table 7: Coefficient Values School Climate Factor as Predictors

\begin{tabular}{clrccr}
\hline Model & Variable & B & Std.Error & Beta & t \\
\hline P1 & Constant & 1.854 & .129 & & 14.369 \\
& Leadership & .594 & .031 & .737 & 19.212 \\
\hline P2 & Constant & 1.507 & .126 & & 11.913 \\
& Leadership & .430 & .035 & .535 & 12.200 \\
& Environment & .241 & .031 & .359 & 7.746 \\
\hline P3 & Constant & 1.162 & .131 & & 8.893 \\
& Leadership & .357 & .035 & .444 & 10.182 \\
& Environment & .199 & .030 & .280 & 6.627 \\
& Instruction & .190 & .030 & .251 & 6.403 \\
\hline P4 & Constant & 1.151 & .128 & & 8.994 \\
& Leadership & .305 & .037 & .379 & 8.243 \\
& Environment & .137 & .034 & .192 & 4.054 \\
& Instruction & .175 & .029 & .231 & 5.962 \\
& Collaboration & .132 & .035 & .192 & 3.766
\end{tabular}

Dependent Variable: School Effectiveness, P=Predicable Variable

Contribution of School Culture and Climate as Predictable Factor for School Effectiveness

Table 8 , shows that both school culture and climate have significant beta $(\beta)$ values. This means that each of these variables explained the variance in school effectiveness significantly after the influence of the other variables was statistically controlled through multiple regression analysis.

Table 8: The Beta Values of the School Culture and Climate

\begin{tabular}{lll}
\hline Variable & Beta & Sig. \\
\hline School Culture & $\beta=.542^{*}$ & .000 \\
School Climate & $\beta=.317^{*}$ & .000 \\
\hline
\end{tabular}

Note: Significant level $p<0.05$

The results of the multiple regression analysis in table 9 and 10 show that school culture variables and school climate are included in the regression model. School culture $(\beta=.794, p<0.5)$ contributed significantly to $63.1 \%\left(R^{2}=.630\right)$ variance change $[F(1,310)=529.974, p<0.5]$. The combination of school culture $(\beta=.542, p<0.5)$ and school climate $(\beta=.317, p<0.5)$ significantly contributed $66.8 \%\left(R^{2}=\right.$ $666)$ of the variance change $[F(2,309)=310.731, p<0.5]$. The result of the Stepwise Multiple Regression analysis shows that: $Y=1.121+0.443_{1}+0.324_{2}$. 
INTERNATIONAL JOURNAL OF ACADEMIC RESEARCH IN BUSINESS AND SOCIAL SCIENCES Vol. 10, No. 5, May, 2020, E-ISSN: 2222-6990 @ 2020 HRMARS

Table 9: Linear regression predictor of School Culture and Climate

\begin{tabular}{llllrrc}
\hline Model & $\boldsymbol{R}$ & $\boldsymbol{R}^{\mathbf{2}}$ & ${ }^{\wedge} \boldsymbol{R}^{\mathbf{2}}$ & \multicolumn{1}{c}{$\mathbf{d f}$} & \multicolumn{1}{c}{$\boldsymbol{F}$} & \multicolumn{1}{c}{ Sig. } \\
\hline School Culture & .794 & .631 & .630 & 1 & 529.974 & .000 \\
& & & & 310 & & \\
& & & & 311 & & \\
\hline School Climate & .817 & .668 & .666 & 2 & 310.731 & .000 \\
& & & & 309 & & \\
& & & & 311 & & \\
\hline
\end{tabular}

Note: Significant level $p<0.05$

The results of the Stepwise Multiple Regression analysis showed that school culture influence $(\beta=.542, p<.05)$ higher than school climate $(\beta=.317, p<.05)$. This model contributes to predicting the impact of school culture and climate on school effectiveness.

Table 10: Coefficient Values of School Culture and Climate

\begin{tabular}{clrccr}
\hline Model & \multicolumn{1}{c}{ Variable } & B & Std.Error & Beta & t \\
\hline P1 & Constant & 1.589 & .119 & & 13.334 \\
& School Culture & .649 & .028 & .794 & 23.021 \\
\hline P3 & Constant & 1.121 & .139 & & 8.088 \\
& School Culture & .443 & .044 & .542 & 10.037 \\
& School Climate & .324 & .055 & .317 & 5.865 \\
\hline
\end{tabular}

Note: $p<0.05$, Dependent Variable: School Effectiveness

\section{Discussion}

This study explains contribution of the school culture and climate for school effectiveness at SJKT in Malaysia. School culture dimension namely; Unity of purpose, collaborative leadership, learning partnership, professional development and teacher's collaboration contributed for $65.0 \%$ changes in variance of school effectiveness. The findings reveal that there is other factor which effect the school effectiveness. Beside that school climate variable dimensions regression model found leadership, environment, instruction and collaboration contribute $67.8 \%$ changes in variance of school effectiveness. There for school culture and climate contributes to school effectiveness in primary Tamil Schools.

In conclusion, the both school culture and climate variables contributes $66.8 \%$ to predicting the impact on school effectiveness as found Maxwell \& Thomas (1991). The both school culture and climate are very important factor that in order to sustain school effectiveness as found by Bellibas and Liu (2018). Unity of purpose, collaborative leadership, learning partnership, professional development and teacher's collaboration are the school culture factors that should focus by school management to enhance ethos (Glisson, 2007). The leadership, environment, instruction, collaboration also among school climate factors that must develop equally to provide better atmosphere for school effectiveness. 
School culture and climate play a major role in the management of school effectiveness. Researchers see culture and climate as an integral part of school management (Minner, 1995; Schein, 1996). However, these two concepts are different and contribute significantly to the development of school effectiveness (Hoy, 1990). This managed as separately can contribute to improving the effectiveness of the school. The findings of this study highlight that school culture and climate contribute separately to the different benefits of school management. Although the combination of the two elements in one management reflects similar contributions, these two factors still differ in the contribution. Therefore, schools are encouraged to take a more proactive approach to addressing this.

\section{References}

Anderson, C. (1982). The search for school climate: A review of the research. Review of Educational Research, 52, 368-420.

Bates, R. J. (1987). Corporate culture, schooling and educational administration. Educational Administration Quarterly, 23(4), 79-115.

Bellibas, M., \& Liu, Y. (2018). The effects of principals' perceived instructional and distributed leadership practices on their perceptions of school climate. International Journal of Leadership in Education, 21(2), 226-244.

Chua, Y. P. (2009). Research Method (5th ed.). Kuala Lumpur: McGraw-Hill.

Glisson, C. (2007). Assessing and changing organizational culture and climate for effective services. Research on Social Work Practice, 17, 736-747.

Gonder, P. O., \& Hymes, D. (1994). Improving School Climate and Culture: AASA Critical Issues Report. Virginia: American association of school administrators.

Gruenert, S. (1998). Development of A School Culture Survey. Doctoral dissertation, University of Missouri - Columbia.

Halpin, A. W., \& Croft D. B. (1963). The Organizational Climate of School. Chicago: Midwest Administration Center, University of Chicago.

Hamidah, Y., \& Cing K. Y. (2014). Principal leadership style and relationship between school effectiveness. Management Research Journal, 3, 93-106.

Houtte, M. V. (2005). Climate or culture? A plea for conceptual clarity in school effectiveness research. School Effectiveness and School Improvement, 16, 71-89.

Hoy, W. K. (1990). Organizational climate and culture: a conceptual analysis of the school workplace. Journal of Educational and Psychological Consultation, 1(2), 149-168.

Hoy, W. K., \& Miskel, C. G. (2013). Educational administration: Theory, research and practice (11th ed.). New York, NY: McGraw-Hill.

Hoy, W. K., Tarter, C. J., Kottkamp, R. B. (1991). Open schools/healthy schools: Measuring organizational climate. Beverly Hills, CA: Sage.

Maxwell, T. W., \& Thomas, A. R. (1991). School climate and school culture. Journal of Educational Administration, 29(2), 72-82.

Mortimore, P. (2001). Globalization, effectiveness and improvement. School Effectiveness and School Improvement, 12, 229-249

Patterson, D. A., Dulmus, C. N., \& Maguin, E. (2012). Empirically supported treatment's impact on organizational culture and climate. Research on Social Work Practice, 22(6), 665-671.

Patterson, D. A., Dulmus, C. N., Maguin, E., \& Critalli, M. (2014). Do organizational culture and climate matter for successful client outcomes? Research on Social Work Practice, 24(6), 670-675. 
INTERNATIONAL JOURNAL OF ACADEMIC RESEARCH IN BUSINESS AND SOCIAL SCIENCES

Vol. 10, No. 5, May, 2020, E-ISSN: 2222-6990 @ 2020 HRMARS

Ross, S. M., \& Lowther, D. L. (2003). Impacts of the co-nect school reform design on classroom instruction, school climate, and student achievement in inner-city schools. Journal of Education for Students Placed at Risk, 8(2), 215-246.

Rudasill, K. M., Snyder, K. E., Levinson, H., \& Adelson, J. L. (2017). Systems view of school climate: a theoretical framework for research. Educational Psychology Review, 1-26.

Schein, E. H. (1990). Organizational culture. American Psychologist, 45(2), 109-119.

Schein, E. H. (1996). Culture: the missing concept in organization studies. Administrative Science Quarterly, 41, 229-240.

Schein, E. H. (2004). The learning culture and the learning leader. In Organizational Culture and Leadership (3rd ed., 393-418). San Francisco, CA: Jossey-Bass.

Zullig, K. J., Koopman, T. M., Patton, J. M., \& Ubbes, V. A. (2010). School climate: Historical review, instrument development, and school assessment. Journal of Psychoeducational Assessment, 28(2), 139-152. 